\title{
A novel association of BoLA DRB3 alleles in BLV infected cattle with different proviral loads
}

\section{Uma nova associação de alelos de BoLA DRB3 em bovinos infectados com BLV com diferentes cargas provirais}

\author{
María Victoria Nieto FARIAS ${ }^{1}$; María Eugenia CAFFARO²; Pamela Anahí LENDEZ; \\ Juan PASSUCCI ${ }^{3}$; Mario POLI ${ }^{2}$; María Carolina CERIANI ${ }^{1}$; Guillermina DOLCINI ${ }^{1}$ \\ ${ }^{1}$ Universidad Nacional del Centro de la Provincia de Buenos Aires, Facultad de Ciencias Veterinarias, \\ Centro de Investigación Veterinaria de Tandil, Laboratorio de Virología, Tandil - Buenos Aires, Argentina \\ ${ }^{2}$ Instituto Nacional de Tecnología Agropecuaria, Centro de Investigación en Ciencias Veterinarias y Agronómicas, \\ Instituto de Genética "Edwald A. Favret" - Buenos Aires, Argentina \\ ${ }^{3}$ Universidad Nacional del Centro de la Provincia de Buenos Aires, Facultad de Ciencias Veterinarias, \\ Área de Epidemiología, Tandil - Buenos Aires, Argentina
}

\begin{abstract}
Bovine leukemia virus (BLV) is associated with the most common neoplastic disease of cattle. BLV has a silent dissemination in the herd due to infected cell exchange, thus the concentration of BLV-infected cells in blood should play a major role in the success of viral transmission. Genes from Bovine leukocyte antigen (BoLA), the MHC system of cattle, are associated with genetic resistance and susceptibility to a wide range of diseases, and also with production traits. Some BoLA DRB3.2 allele polymorphisms in Holstein cattle have been associated with resistance or susceptibility to BLV-disease development, or with proviral load (PVL). This investigation studied 107 BLV-infected Argentinean Holstein dairy cows, all of them belonging to one herd. PVL was analysed by qPCR and animals were classified as high proviral load (HPVL, $N=88$ ) and low proviral load (LPVL, $N=19$ ), and BoLA DRB3.2 alleles were genotyped. Alleles $B o L A D R B 3.2^{\star} 1501$ and ${ }^{\star} 1201$ were significantly associated with HPVL $(p=0.0230$ and $p=0.0111$ respectively), while allele BoLA DRB3. $2^{\star} 0201$ was significantly associated with LPVL $(p=0.0030)$. The present study aims at contributing to the knowledge of the association between BoLA polymorphism and development of a BLV infection profile. Genes that best explain the PVL in this population resulted BoLA DRB3.2 ${ }^{\star} 0201$ (as a protection factor) and ${ }^{\star} 1501$ (as a risk factor). Allelic differences may play an important role in the development of effective immune responses. A better understanding of how BoLA polymorphism contributes to these responses and the establishment of a BLV status is desirable to schedule and evaluate control measures.
\end{abstract}

Keywords: BLV. Proviral load. BoLA DRB3 polymorphism.

\section{Resumo}

$\mathrm{O}$ vírus da leucemia bovina (BLV) está associado à doença neoplásica mais comum do gado bovino. O BLV tem uma disseminação silenciosa no rebanho devido à troca de células infectadas, assim, a concentração de células BLV infectadas no sangue deve desempenhar um papel importante no sucesso da transmissão viral. Os genes do antígeno leucocitário bovino $(B o L A)$, sistema $\mathrm{MHC}$ do gado bovino, estão associados à resistência genética e à susceptibilidade a uma ampla gama de doenças, bem como às características da produção. Alguns polimorfismos de alelos de BoLA DRB3.2 em bovinos Holstein têm sido associados à resistência ou susceptibilidade ao desenvolvimento da doença BLV, ou com carga proviral (PVL). Esta investigação avaliou 107 vacas leiteiras da raça Holstein argentina infectadas com BLV e pertencentes a um único rebanho. A PVL foi analisada por qPCR, os animais foram classificados em alta carga proviral (HPVL, $\mathrm{N}=88$ ) e baixa carga proviral (LPVL, $\mathrm{N}=19$ ), e os alelos BoLA DRB3.2 foram genotipados. Os alelos BoLA $D R B 3.2 * 1501$ e ${ }^{\star} 1201$ estavam significativamente relacionados à HPVL ( $p=0,0230$ e $p=0,0111$, respectivamente), enquanto o alelo BoLA DRB3.2 $2^{*} 201$, à LPVL $(p=0,0030)$. O objetivo deste estudo é contribuir para o conhecimento da associação entre o polimorfismo de BoLA e o desenvolvimento de infecção por BLV. Os genes que melhor explicam a PVL na população analisada resultaram em BoLA DRB3.2 0201 (como fator de proteção) e ${ }^{\star} 1501$ (como fator de risco). As diferenças alélicas podem desempenhar um papel importante no desenvolvimento de respostas imunitárias eficazes. Uma melhor compreensão de como o polimorfismo BoLA contribui para estas respostas e o estabelecimento de um estado BLV é desejável para agendar e avaliar as medidas de controle.

Palavras-chave: BLV. Carga proviral. Polimorfismo do BoLA DRB3. 
Correspondence to:

Guillermina Dolcini

Pasaje Arroyo Seco, s/n

B7000, Tandil, Argentina

e-mail: gdolcini@vet.unicen.edu.ar

Received: 06/12/2016

Approved: 02/08/2017

\section{Introduction}

Bovine leukemia virus (BLV) shares the genomic organization structure with T-cell tropic viruses from primates (human and simian), and constitute a unique subgroup within the Retroviridae family, characterized by distinct genetic content, genomic organization, and strategy for gene expression (COFFIN, 1996). BLV is associated with enzootic bovine leucosis (EBL), which is the most common neoplastic disease of cattle. Most infected cattle remain asymptomatic. By contrast, approximately $30 \%$ of cattle develop persistent lymphocytosis (PL), which is characterized as the polyclonal expansion of non-neoplastic CD5+ B-lymphocytes. PL often precedes tumorigenesis but is usually regarded as clinically healthy. After a latency period of 1-8 years, less than $10 \%$ of infected cattle develop EBL, which is a malignant CD5 ${ }^{+}$ B-cell lymphoma (FERRER, 1980; GILLET et al., 2007). BLV has a silent dissemination in the herd due to infected cell exchange (HOPKINS; DIGIACOMO, 1997), thus the concentration of BLV-infected cells in blood should play a major role in the success of viral transmission. Even though PL cattle are considered the most risky for transmission, asymptomatic animals may also play a role depending on their proviral load (JULIARENA et al., 2007).

The major histocompatibility complex (MHC) molecules are responsible for presentation of processed antigen peptides to $\mathrm{T}$ cells, and thereby an adaptive immune response to specific pathogens is trigged. The high degree of polymorphism of the MHC molecules enables the presentation of a wide array of peptides that differ in their length and sequence. Thus, the nature and strength of the immune responses depend on the peptide and the MHC molecules, and may influence disease progression (AMILLS et al., 1998). Bovine leukocyte antigen (BoLA), the MHC system of cattle, is highly polymorphic. Functionally, the BoLA class II gene is classified into two groups, $D R$ and $D Q$. The $D R A$ and $D R B 3$ gene products form the $D R$ molecule, as $D R B 3$ is the only functional $D R B$ gene within BoLA (TAKESHIMA; AIDA, 2006).
Genes from BoLA are remarkably attractive to animal breeders and veterinary geneticist, and polymorphism in BoLA genes has been relatively well studied. These genes are associated with genetic resistance and susceptibility to a wide range of diseases, including mastitis (DIETZ et al., 1997; RUPP et al., 2007; YOSHIDA et al., 2009; YOSHIDA et al., 2012), dermatophilosis (MAILLARD et al., 2002), tick-borne diseases (DUANGJINDA et al., 2013), infection with Neospora caninum (SCHWAB et al., 2009), African trypanosome species (KARIMURIBO et al., 2011), and Theileria annulata (GLASS et al., 2012b). Moreover, BoLA appears to influence other traits such as milk yield, growth and reproduction, and variations in immune responses to antigens (TAKESHIMA; AIDA, 2006) and even vaccine peptides (GARCIA-BRIONES et al., 2000; GLASS et al., 2012a).

The greatest amount of evidence linking BoLA gene polymorphisms and disease outcome is given by BLV infection. First evidences revealed an association between resistance or susceptibility to PL and BoLA A class I alleles (LEWIN; BERNOCO, 1986); however, these associations were relatively weak at population levels and different BoLA $A$ alleles had significant effects in different breeds (LEWIN et al., 1988; STEAR et al., 1988). Subsequent studies showed that resistance and susceptibility to PL map more closely to MHC class II BoLA DRB3.2 gene than to BoLA A locus (ESTEBAN et al., 2009). Thus, most studies have focused on BOLA DRB3.2 allele polymorphisms in Holstein cattle, and their relationship with disease. Some alleles were associated with resistance to PL or to BLV-induced lymphosarcoma, or the capability of controlling the number of BLV-infected cells, while other alleles were associated with susceptibility to PL (XU et al., 1993; ZANOTTI et al., 1996; MIRSKY et al., 1998; PANEI et al., 2009; NIKBAKHT BRUJENI et al., 2016). When BLV-infected animals were characterized into two profiles of infection - high and low proviral load (HPVL and LPVL respectively) (JULIARENA et al., 2007), BoLA DRB3.2 ${ }^{*} 0902$ allele was the strongest associated with LPVL profile, while ${ }^{\star} 1501$ or 03 allele showed a significant association with HPVL in carrier animals (JULIARENA et al., 2008). Miyasaka et al. (2013) also analyzed the effect of BoLA DRB3.2 alleles on proviral load in Japanese cattle and found that ${ }^{*} 0902$ and ${ }^{*} 1101$ alleles were associated with LPVL and ${ }^{*} 1601$ allele with HPVL and identified BoLA class II haplotypes that correlated with different PVL status.

In the present investigation we analysed whether HPVL or LPVL status in the BLV-infected animals from the herd 
under study were associated with specific BoLA DRB3.2 alleles. This study aims at contributing to the knowledge of the association between BoLA polymorphism and development of a BLV infection profile.

\section{Material and Methods}

\section{Sample collection}

Blood samples were obtained from 107 BLV-infected Argentinean Holstein (Holando-Argentino) dairy cows belonging to a herd from the Tandil region (Provincia de Buenos Aires, Argentina). All animals were healthy and milking (between second and third lactation period) and although the pedigree information was not complete for $3 \%$ of them, they came from at least 51 and 87 different bulls and cows, respectively. Serological BLV status was determined by testing plasma for anti-gp51 antibodies by ELISA 108 (GUTIERREZ et al., 2001). For peripheral blood mononuclear cells (PBMCs) separation, $10 \mathrm{~mL}$ blood samples were collected in heparinized syringes by jugular venipuncture. Blood samples were transferred to $15 \mathrm{~mL}$ tubes and centrifuged for $15 \mathrm{~min}$ at $3800 \mathrm{rpm}$ at $4^{\circ} \mathrm{C}$. Buffy coat was mixed with $11 \mathrm{~mL}$ of cold ammonium chloride buffer $\left(150 \mathrm{mM} \mathrm{NH}_{4} \mathrm{Cl}, 8 \mathrm{mM} \mathrm{Na}_{2} \mathrm{CO}_{3}\right.$, and $6 \mathrm{mM}$ EDTA) for red blood cells lysis. PBMCs were obtained by centrifugation at $3000 \mathrm{rpm}$ for $10 \mathrm{~min}$ at $4^{\circ} \mathrm{C}$. Cells were washed with PBS and centrifuged at $2500 \mathrm{rpm}$ for 7 $\min$ at $4^{\circ} \mathrm{C}$. PBMCs pellets were stored at $-20^{\circ} \mathrm{C}$ for DNA extraction.

\section{DNA extraction}

DNA from PBMCs was extracted using Qiagen columns (QIAamp DNA Mini Kit) according to the manufacturer's protocol. DNA was eluted in $50 \mathrm{ml}$ of water. The concentration and purity of DNA were determined by the OD value at $260 \mathrm{~nm}$ and $260 / 280$ coefficient respectively in a NanoDrop 2000 Spectrophotometer (Thermo Scientific). The purified DNAs were stored at $-20^{\circ} \mathrm{C}$ until use.

\section{Proviral load determination by real-time PCR ( $q P C R$ )}

The absolute quantification method by qPCR used for proviral load (PVL) determination was the one described by Farias et al. (2016). The standard curve was constructed using a plasmid carrying one copy of the entire BLV genome under control of its own promoter LTR (pBLV), with six 10-fold serial dilutions of pBLV, containing 1 million to $10 \mathrm{BLV}$ copies. The qPCR conditions for $p o l$ amplification were previously described (FARIAS et al., 2016). Each reaction contained $30 \mathrm{ng}$ of DNA from BLVinfected animals. The standard curve and non-template control were included in each run. Experiments were always performed in triplicate. BLV-positive animals were classified as high proviral load (HPVL) (> $1000 \mathrm{BLV}$ copies/reaction) and low proviral load (LPVL) $(<100 \mathrm{BLV}$ copies/reaction). Before classifying the animals into each group, the proviral load was evaluated twice at 6-months intervals, in order to confirm their PVL. Eighty-eight out of 107 animals were HPVL, while the remaining 19 proved to be LPVL.

\section{BoLA DRB3.2 genotyping}

PCR reactions were performed in a final volume of 15 $\mathrm{L}$, where the volume mixture contained: ng of genomic DNA, 0.03 X PCR buffer ( $\mathrm{Mg}^{2+}$ plus), $0.3 \mathrm{M}$ of each primer (HL030; 5'-ATCCTCTCTCTGCAGCACATTTCC-3', and HL031; 5'-TTTAAATTCGCGCTCACCTCGCCGCT-3'), $0.2 \mathrm{mM}$ of dNTP and $0.75 \mathrm{U}$ Paq5000 ${ }^{\circledR}$ DNA Polymerase (Agilent Technologies, Stratagene) and water up to a total volume of $15 \mu \mathrm{L}$. Conditions for amplification were $94^{\circ} \mathrm{C}$ for $3 \mathrm{~min}$, followed by 35 cycles of $20 \mathrm{~s}$ at $94^{\circ} \mathrm{C}, 20 \mathrm{~s}$ at $60^{\circ} \mathrm{C}$ (annealing temperature), and $1 \mathrm{~min}$ at $72^{\circ} \mathrm{C}$. Reactions were finished with a $72^{\circ} \mathrm{C}, 5$-min extension. PCR reactions were performed in a Mastercycler (Eppendorf ${ }^{\circledR}$ ) thermocycler. Amplified fragments of DNA were visualized in a $1 \%$ agarose gel and sequenced using BigDye ${ }^{\circledR}$ chemistry on an ABI3130xl sequencer (Applied Biosystems) following the manufacturer's protocol. Sequencing reactions were performed in both senses using the same primers as for PCR reactions, in a total volume of $10 \mathrm{~L}$ containing a 1:10 dilution of the PCR product as template and $0.1 \mathrm{M}$ of primer, in addition to the mix and buffer $5 \mathrm{X}$ of BigDye ${ }^{\circledR}$ Terminator kit. The sequence analysis and obtaining genotypes was performed using Haplofinder (BAXTER et al., 2008).

\section{Statistics analysis}

Association between different BoLA DRB3.2 alleles and proviral load was estimated by $\mathrm{Chi}^{2}$ test or exact Fisher test, as appropriate, implemented by PROC FREQ (SAS v9.3, Institute Inc., Cary, NC, USA). With genes that were significant to the bivariate analysis logistic regression was performed in order to identify genes that best explain the CPV, using the PROC LOGISTIC (SAS v9.3). 


\section{Results}

\section{Analysis of BoLA DRB3.2 genotyping}

After genotyping, a total of 18 BoLA DRB3.2 alleles defined according to the ISAG BoLA Nomenclature Committee were identified in these Argentinean Holstein cattle. The five most frequently alleles were BoLA DRB3. ${ }^{\star} 1001$ (17.29\%), ${ }^{\star} 1501$ (16.36\%), ${ }^{\star} 1101$ (14.95\%), ${ }^{\star} 0101(12.15 \%)$, and ${ }^{\star} 1201(11.21 \%)$ (Table 1). We found 47 genotypes, where BoLA DRB3.2*1001+BoLADRB3. $2^{*} 1501$ (9 animals, 18.75\%), BoLA DRB3.2*1101 + BoLA DRB3. ${ }^{*} 1501$ (8 animals, 16.67\%), and BoLA DRB3. ${ }^{\star} 1001+$ BoLA DRB3. ${ }^{*} 1201$ (6 animals, $\left.12.5 \%\right)$ were the most frequent in the population (data not shown).

Table 1 - BoLA DRB3.2 allele frequency in the studied population

\begin{tabular}{ccc}
\hline Alelle & No. & $\%$ \\
\hline$* 1001$ & 37 & 17.29 \\
$* 1501$ & 35 & 16.36 \\
$* 1101$ & 32 & 14.95 \\
$* 0101$ & 26 & 12.15 \\
$* 1201$ & 24 & 11.21 \\
$* 0201$ & 14 & 6.54 \\
$* 0902$ & 9 & 4.21 \\
$* 0601$ & 7 & 3.27 \\
$* 1801$ & 6 & 2.80 \\
$* 2703$ & 5 & 2.34 \\
$* 14011$ & 5 & 2.34 \\
$* 3103$ & 4 & 1.87 \\
$* 1001 / 1002$ & 3 & 1.40 \\
$* 1402$ & 2 & 0.93 \\
$* 2707$ & 2 & 0.93 \\
$* 0701$ & 1 & 0.47 \\
$* 1701$ & 1 & 0.47 \\
$* 2003$ & & 0.47 \\
\hline & 2 &
\end{tabular}

\section{Association between BoLA DRB3.2 alleles and proviral load (PVL)}

BLV-positive cattle $(N=107)$ were categorized into two groups according to their PVL by qPCR: 88 had HPVL and 19 had LPVL. The presence or absence of each BoLA DRB3.2 allele in this cattle population was analysed in association with PVL (Table 2). No significant association was observed between PVL and alleles having frequency lower than 10\%. Amongst alleles with higher frequency in the population, ${ }^{\star} 1501$ and ${ }^{\star} 1201$ were significantly associated with HPVL $(p=0.0230$ and $p=0.0111$ respectively), while allele ${ }^{\star} 0201$ was significantly associated with LPVL $(p=0.0030)$ (Table 2$)$.

Table 2 - Association between BoLA DRB3.2 alleles and proviral load (PVL)

\begin{tabular}{|c|c|c|c|c|c|}
\hline $\begin{array}{l}\text { Evaluated } \\
\text { allele }\end{array}$ & PVL & $\begin{array}{l}\text { Presence } \\
\text { (No.) }\end{array}$ & $\begin{array}{c}\text { Absence } \\
\text { (No.) }\end{array}$ & $\begin{array}{c}\text { OR } \\
\text { (CI } \\
95 \%)\end{array}$ & $p$ value \\
\hline *1001 & $\begin{array}{l}\text { HPVL } \\
\text { LPVL }\end{array}$ & $\begin{array}{c}33 \\
3\end{array}$ & $\begin{array}{l}56 \\
16\end{array}$ & & $0.0830^{\mathrm{a}}$ \\
\hline *1501 & $\begin{array}{l}\text { HPVL } \\
\text { LPVL }\end{array}$ & $\begin{array}{c}33 \\
2\end{array}$ & $\begin{array}{l}55 \\
17\end{array}$ & $\begin{array}{c}5.10 \\
(1,27- \\
20,53)\end{array}$ & $0.0230^{a}$ \\
\hline *1101 & $\begin{array}{l}\text { HPVL } \\
\text { LPVL }\end{array}$ & $\begin{array}{c}24 \\
5\end{array}$ & $\begin{array}{l}64 \\
14\end{array}$ & & $0.9322^{\mathrm{a}}$ \\
\hline *0101 & $\begin{array}{l}\text { HPVL } \\
\text { LPVL }\end{array}$ & $\begin{array}{c}20 \\
6\end{array}$ & $\begin{array}{l}68 \\
13\end{array}$ & & $0.3947^{b}$ \\
\hline *1201 & $\begin{array}{l}\text { HPVL } \\
\text { LPVL }\end{array}$ & $\begin{array}{c}23 \\
0\end{array}$ & $\begin{array}{l}65 \\
19\end{array}$ & ------- & $0.0111^{b}$ \\
\hline *0201 & $\begin{array}{l}\text { HPVL } \\
\text { LPVL }\end{array}$ & $\begin{array}{l}7 \\
7\end{array}$ & $\begin{array}{l}81 \\
12\end{array}$ & $\begin{array}{c}0.15 \\
(0.05- \\
0.48)\end{array}$ & $0.0030^{b}$ \\
\hline *0902 & $\begin{array}{l}\text { HPVL } \\
\text { LPVL }\end{array}$ & $\begin{array}{l}7 \\
2\end{array}$ & $\begin{array}{l}81 \\
17\end{array}$ & & $0.6594^{b}$ \\
\hline${ }^{*} 0601$ & $\begin{array}{l}\text { HPVL } \\
\text { LPVL }\end{array}$ & $\begin{array}{l}5 \\
2\end{array}$ & $\begin{array}{l}83 \\
17\end{array}$ & & $0.6051^{b}$ \\
\hline *1801 & $\begin{array}{l}\text { HPVL } \\
\text { LPVL }\end{array}$ & $\begin{array}{l}5 \\
1\end{array}$ & $\begin{array}{l}83 \\
18\end{array}$ & & $1^{b}$ \\
\hline *2703 & $\begin{array}{l}\text { HPVL } \\
\text { LPVL }\end{array}$ & $\begin{array}{l}4 \\
1\end{array}$ & $\begin{array}{l}84 \\
18\end{array}$ & & $1^{\mathrm{b}}$ \\
\hline *3103 & $\begin{array}{l}\text { HPVL } \\
\text { LPVL }\end{array}$ & $\begin{array}{l}4 \\
0\end{array}$ & $\begin{array}{l}84 \\
19\end{array}$ & & $1^{\mathrm{b}}$ \\
\hline *14011 & $\begin{array}{l}\text { HPVL } \\
\text { LPVL }\end{array}$ & $\begin{array}{l}1 \\
2\end{array}$ & $\begin{array}{l}87 \\
17\end{array}$ & & $0.0807^{b}$ \\
\hline${ }^{*} 1001 / * 1002$ & $\begin{array}{l}\text { HPVL } \\
\text { LPVL }\end{array}$ & $\begin{array}{l}1 \\
2\end{array}$ & $\begin{array}{l}87 \\
17\end{array}$ & & $0.0807^{b}$ \\
\hline *1402 & $\begin{array}{l}\text { HPVL } \\
\text { LPVL }\end{array}$ & $\begin{array}{l}2 \\
0\end{array}$ & $\begin{array}{l}86 \\
19\end{array}$ & & $1^{\mathrm{b}}$ \\
\hline *2707 & $\begin{array}{l}\text { HPVL } \\
\text { LPVL }\end{array}$ & $\begin{array}{l}1 \\
1\end{array}$ & $\begin{array}{l}87 \\
18\end{array}$ & & $0.3250^{b}$ \\
\hline$* 0701$ & $\begin{array}{l}\text { HPVL } \\
\text { LPVL }\end{array}$ & $\begin{array}{l}1 \\
0\end{array}$ & $\begin{array}{l}87 \\
19\end{array}$ & & $1^{\mathrm{b}}$ \\
\hline$* 1701$ & $\begin{array}{l}\text { HPVL } \\
\text { LPVL }\end{array}$ & $\begin{array}{l}0 \\
1\end{array}$ & $\begin{array}{l}88 \\
18\end{array}$ & & $0.1776^{b}$ \\
\hline *2003 & $\begin{array}{l}\text { HPVL } \\
\text { LPVL }\end{array}$ & $\begin{array}{l}1 \\
0\end{array}$ & $\begin{array}{l}87 \\
19\end{array}$ & & $1^{\mathrm{b}}$ \\
\hline
\end{tabular}

Values in bold are statistically significant - odds ratios with $p<0.05$ ${ }^{\text {a }} \mathrm{Chi}^{2}$ test

${ }^{\mathrm{b}}$ Exact Fisher test 


\section{Distribution of BoLA DRB3.2 alleles significantly associated with $P V L$}

BoLA DRB3. $2^{\star} 1501,{ }^{\star} 1201$, and ${ }^{\star} 0201$ were significantly associated with PVL. Contrasts were estimated in order to compare absence and presence of each one in homozygous and heterozygous form.

BoLA DRB3. $2^{\star} 1501$ allele is present in heterozygosis in $94 \%$ of HPVL animals; animals that carry it are about 5 times more likely to have HPLP (Chi ${ }^{2}$ test: $p=0.0230$ ) (Table 3). BoLA DRB3.2*1201 allele is present only in HPVL animals (Fisher exact test: $p=0.0187$ ) (Table 4 ). BoLA DRB3. $2^{*} 0201$ allele is present in heterozygous in $50 \%$ of HPVL animals and 50\% of LPVL animals; among animals that do not possess this allele, $87 \%$ have HPVL (Fisher exact test: $p=0.0030$ ) (Table 5). Thus, animals that have ${ }^{\star} 0201$ allele would be protected to develop HPVL.

Table 3 - Distribution of BoLA DRB3.2*1501

\begin{tabular}{|c|c|c|c|}
\hline $\begin{array}{ll}\text { Genotype } & \text { PVL } \\
\end{array}$ & HPVL & LPVL & Total \\
\hline Homozygote & 0 & 0 & 0 \\
\hline Heterozygote & 33 & 2 & 35 \\
\hline Absence & 55 & 17 & 72 \\
\hline Total & 88 & 19 & 107 \\
\hline
\end{tabular}

Chi ${ }^{2}$ test: $p=0.0230$; OR $5.10($ CI $1.27-20.53)$

Table 4 - Distribution of BoLA DRB3.2*1201

\begin{tabular}{|c|c|c|c|}
\hline Genotype & HPVL & LPVL & Total \\
\hline Homozygote & 1 & 0 & 1 \\
\hline Heterozygote & 22 & 0 & 22 \\
\hline Absence & 65 & 19 & 84 \\
\hline Total & 88 & 19 & 107 \\
\hline
\end{tabular}

Fisher exact test: $p=0.0187$; OR between groups cannot be estimated

Table 5 - Distribution of BoLA DRB3.2*0201

\begin{tabular}{|c|c|c|c|}
\hline $\begin{array}{r}\text { PVL } \\
\end{array}$ & HPVL & LPVL & Total \\
\hline Homozygote & 0 & 0 & 0 \\
\hline Heterozygote & 7 & 7 & 14 \\
\hline Absence & 81 & 12 & 93 \\
\hline Total & 88 & 19 & 107 \\
\hline
\end{tabular}

Fisher exact test: $p=0.0030$; OR $0.15(\mathrm{CI} 0.05-0.48)$
A logistic regression model was run with the BoLA DRB3. $2^{\star} 0201$ and ${ }^{\star} 1501$ alleles as the independent variables, and the HPVL profile as the dependent variable. This analysis indicated that ${ }^{*} 0201$ allele is a protective factor $(p=0.0024)$, while ${ }^{*} 1501$ allele is a risk factor $(p=0.0341)$ for HPVL profile (Table 6). Thus, genes that best explain the PVL are BoLA DRB3.2 $2^{\star} 0201$ (as a protection factor) and ${ }^{\star} 1501$ (as a risk factor), with no significant interaction estimated between them ( $p=0.957)$.

Table 6 - Logistic regression for BoLA DRB3.2 ${ }^{\star} 0201$ or ${ }^{\star} 1501$ alleles and HPVL profile

\begin{tabular}{ccc}
\hline $\begin{array}{c}\text { Independent } \\
\text { variables }\end{array}$ & $\begin{array}{c}\text { OR } \\
(\mathbf{C l ~ 9 5 \% )}\end{array}$ & $p$ value \\
\hline BoLA DRB3. $2 * 0201$ & 0.13 & 0.0024 \\
BoLA DRB3. $2 * 1501$ & $(0.04-0.49)$ & \\
& 5.65 & 0.0341 \\
\hline
\end{tabular}

\section{Discussion}

This study analysed the distribution of BoLA DRB3.2 alleles in an Argentinean Holstein herd and its association with the BLV proviral load. In this group of animals $(N=107)$, we identified 18 alleles and BoLA DRB3.2*1001 had the highest allelic frequency (17.29\%). There is not too much information about the allelic diversity of BoLA DRB3 class II gene in different cattle breeds. As far as it is known, only one study described this diversity in South American Holstein populations (TAKESHIMA et al., 2015). These authors found that BoLA DRB ${ }^{*} 1501$ appeared to be widely spread in the cattle of countries of South America: 18.2\% in Bolivia, 17.7\% in Paraguay, $21.4 \%$ in Peru, $21,7 \%$ in Chile, and $14.7 \%$ in Argentina. In the present investigation we found a slightly higher frequency of this allele in our population (16.36\%). BoLA $D R B 3^{*} 0101$ and ${ }^{*} 1101$ were also in high frequency in these Holstein population of South American countries. Even though $B o L A D R B 3^{\star} 0101$ was the most frequently found in Argentina (17.7\%), its presence was lower by one third in our population $(12.15 \%)$. The greatest differences in allelic frequency between Takeshima's and in the present study were in BoLA DRB ${ }^{\star} 1201$ (7.3\% vs $\left.11.21 \%\right),{ }^{\star} 1001$ ( $5 \%$ vs $17.29 \%$ ), and ${ }^{\star} 0201$ (3.2\% vs $6.54 \%$ ). The highest frequency of the analysed alleles found in this research could be a result of the selection for trait parameters applied in our herd. And this fact might have implications 
on susceptibility or resistance to diseases, immunological and production trails, and vaccine responses.

Related to the infection with BLV in Holstein breed, several studies have shown that the susceptibility to PL was associated with the presence of BoLA DRB $3^{\star} 0101$, ${ }^{\star} 1501$ or $03,{ }^{\star} 1101$ or 02 , and ${ }^{\star} 1201$ (XU et al., 1993; ZANOTTI et al., 1996; MIRSKY et al., 1998; JULIARENA et al., 2008; PANEI et al., 2009; NIKBAKHT BRUJENI et al., 2016). In the present study, BoLA DRB ${ }^{\star} 1201$ was the most significantly associated with HPVL $(p=0.0111)$, and this might be due to the fact that its frequency in the investigated population was about one third higher than in other Argentinean Holstein populations (11.21\% vs $7.3 \%$, respectively) (TAKESHIMA et al., 2015). In this investigation we also found a strong association between HPVL and the presence of BoLA DRB3 ${ }^{\star} 1501$ ( $\left.p=0.0230\right)$. These two alleles are the most frequently associated with susceptibility to PL or HPVL in BLV-infected animals from different cattle breeds (XU et al., 1993; SULIMOVA et al., 1995; ZANOTTI et al., 1996; UDINA et al., 2003; JULIARENA et al., 2008). BoLA DRB3*1001 had the highest frequency in the investigated herd, and in the literature it was referred as a susceptible (XU et al., 1993; UDINA et al., 2003) or a neutral allele (XU et al., 1993) for PL development. However, no association with BLV status could be established in BoLA DRB ${ }^{*} 1001$ carrier animals from the present study. In Japanese cattle, Miyasaka et al. (2013) found that ${ }^{\star} 1601$ allele was associated with HPVL, but in this investigation no animals were identified carrying this allele.

Resistance to PL or an LPVL profile were associated with alleles that are generally less distributed in cattle population. In the present investigation we found a strong association between DRB3.2*0201 and LPVL ( $p=0.030$ ). It is possible to speculate that the absence of this allele could be an indicative of a putative development of HPVL (Table 5). Panei et al. (2009) studied a herd of 81 Argentinean Holstein animals by PCR-RFLP and mentioned BoLA DRB3. $2^{\star} 11,{ }^{\star} 23,{ }^{\star} 28,{ }^{\star} 25$, and ${ }^{\star} 40$ (ISAG ${ }^{\star} 0902,{ }^{\star} 2703$, ${ }^{\star} 0701$ or 03 , and non-classified respectively) as associated with PL resistance; but in the present investigation we did not find the same results. Even though several studies cited ${ }^{*} 1101$ linked to PL susceptibility in different cattle breeds (XU et al., 1993; SULIMOVA et al., 1995; UDINA et al., 2003; PANEI et al., 2009; NIKBAKHT BRUJENI et al., 2016), it was associated with LPVL in Japanese cattle (MIYASAKA et al., 2013). In the present investigation we found a significant number of animals carrying this allele in our herd, compared to the population of Holstein in Argentina (TAKESHIMA et al., 2015); however, no association could be established between allele BoLA DRB3. $2^{*} 1101$ and BLV PVL. In the literature BoLA DRB3. ${ }^{\star} 0902$ (or ${ }^{\star} 11$ determined by PCR-RFLP) allele was most strongly associated with PL resistance or LPVL profile in Holstein cattle (XU et al., 1993; ZANOTTI et al., 1996; MIRSKY et al., 1998; JULIARENA et al., 2008; PANEI et al., 2009; MIYASAKA et al., 2013). In the present investigation we did not find this association, which could be due to a lower frequency of presentation of ${ }^{\star} 0902$ allele in this herd in comparison with the Argentinean Holstein populations ( $4.21 \%$ vs $6.4 \%$, respectively) (TAKESHIMA et al., 2015).

Genetic selection for BoLA DRB3.2*0902 allele has been proposed to breed cattle that are resistant to HPVL development (JULIARENA et al., 2016). Evidences from the literature reveal that the polymorphism in the BoLA class II gene influences immune response by peptide binding, antigen presentation, T-cell repertoire, and cytokine networks (TAKESHIMA; AIDA, 2006). Thus, allelic differences in BLV-infected animals may play an important role in the development of effective immune responses. However, BLV-resistance might not be only related to a single allele of the DRB3.2 gene. Indeed, about $19 \%$ of cattle carrying the BoLA DRB3.2 ${ }^{\star} 0902$ allele develop HPVL (JULIARENA et al., 2008). It must be considered that expression of BoLA DRB3 might be influenced by polymorphisms in other surrounding genes. An important gene of the immune system that has been linked to the BoLA region is the promoter region of tumor necrosis factor-alpha (TNF- $\alpha$ ): both genes are located in the q22 arm of the bovine chromosome 23 and in linkage disequilibrium (LENDEZ et al., 2015). Concerning BLV infection, TNF- $\alpha$ is closely related with the immune response against viral dissemination, stimulating the elimination of infected lymphocytes (KABEYA et al., 1999). Konnai et al. (2006) described that genotype $\mathrm{G} / \mathrm{G}$ in position -824 of the promoter region of TNF- $\alpha$ was associated with low transcriptional activity of the promoter region. The frequency of this genotype $G / G$ was higher in individuals with BLV-induced lymphoma than in asymptomatic carrier individuals. Moreover, a tendency toward an increased BLV provirus load in cattle with the TNF- $\alpha-824$ G/G homozygote was observed when compared to the A/A homozygote or genotype A/G. 
Lendez et al. (2015), analysing a large population of cattle with HPVL or LPVL, revealed a significant association between LPVL and a low frequency of the G/G genotype at position -824. That means that an animal carrying this polymorphism most probably belongs to the HPVL group. In the present study we also analysed the polymorphism in the promoter region of TNF- $\alpha$; however, no statistical differences were found between animals with HPVL or LPVL (data not shown), probably due to the small number of animals with LPVL. Taking together, it seems that several polymorphisms in different genes may contribute to develop a resistance profile in BLV-infected cattle.

On the other hand, other issues like production traits improvement, resistance to mastitis pathogens, somatic cell counts and milk yield have also been related to specific BoLA alleles (DIETZ et al., 1997; RUPP et al., 2007; YOSHIDA et al., 2009; BALTIAN et al., 2012; YOSHIDA et al., 2012). However, some controversies exist between different studies. Abdalla et al. (2016) communicated a genome-wide association mapping in order to analyse BLV incidence in US Holstein cattle population, together

\section{References}

ABDALLA, E. A.; PEÑAGARICANO, F.; BYREM, T. M.; WEIGEL, K. A.; ROSA, G. J. Genome-wide association mapping and pathway analysis of leukosis incidence in a US Holstein cattle population. Animal Genetics, v. 47, n. 4, p. 395-407, 2016. doi: 10.1111/age.12438.

AMILLS, M.; RAMIYA, V.; NORIMINE, J.; LEWIN, H. A. The major histocompatibility complex of ruminants. Revue Scientifique et Technique, v. 17, n. 1, p. 108-120, 1998. doi: 10.20506/rst.17.1.1092.

BALTIAN, L. R.; RIPOLI, M. V.; SANFILIPPO, S.; TAKESHIMA, S. N.; AIDA, Y.; GIOVAMBATTISTA, G. Association between BoLA-DRB3 and somatic cell count in Holstein cattle from Argentina. Molecular Biology Reports, v. 39, n. 7, p. 7215-7220, 2012. doi: 10.1007/s11033012-1526-y.

BAXTER, R.; HASTINGS, N.; LAW, A.; GLASS, E. J. A rapid and robust sequence-based genotyping method for BoLA-DRB3 alleles in large numbers of heterozygous cattle. Animal Genetics, v. 39, n. 5, p. 561-563, 2008. doi: 10.1111/j.1365-2052.2008.01757.x. with milk yield and somatic cell score, combining pedigree and molecular marker information, for the detection of genomic regions and gene pathways associated with the disease. The study revealed BLV incidence as a complex trait, possibly modulated by several genes of small effects.

\section{Conclusions}

The association between BoLA polymorphism and development of a BLV infection profile was investigated. Genes that best explain the PVL in this population resulted BoLA DRB3. $2^{\star} 0201$ (as a protection factor) and ${ }^{\star} 1501$ (as a risk factor). Allelic differences may play an important role in the development of effective immune responses, against BLV and other pathogens. Thus, genetic selection based on specific BoLA alleles should be implemented with great caution considering the variable effects of these genes on a wide range of diseases and production traits. A better understanding of how BoLA polymorphism contributes to the development of effective immune response and the establishment of a BLV status is desirable to schedule and evaluate control measures.

COFFIN, J. M. Retrovirus restriction revealed. Nature, v. 382 , n. 6594 , p. $762-763$, 1996. doi: 10.1038/382762a0.

DIETZ, A. B.; DETILLEUX, J. C.; FREEMAN, A. E.; KELLEY, D. H.; STABEL, J. R.; KEHRLI JUNIOR, M. E. Genetic association of bovine lymphocyte antigen DRB3 alleles with immunological traits of Holstein cattle. Journal of Dairy Science, v. 80, n. 2, p. 400-405, 1997. doi: 10.3168/jds.S0022-0302(97)75950-2.

DUANGJINDA, M.; JINDATAJAK, Y.; TIPVONG, W.; SRIWAROTHAI, J.; PATTARAJINDA, V.; KATAWATIN, S.; BOONKUM, W. Association of BoLA-DRB3 alleles with tick-borne disease tolerance in dairy cattle in a tropical environment. Veterinary Parasitology, v. 196, n. 3-4, p. 314-320, 2013. doi: 10.1016/j.vetpar.2013.03.005.

ESTEBAN, E. N.; POLI, M.; POIESZ, B.; CERIANI, C.; DUBE, S.; GUTIERREZ, S.; DOLCINI, G.; GAGLIARDI, R.; PEREZ, S.; LÜTZELSCHWAB, C.; FELDMAN, L.; JULIARENA, M. A. Bovine leukemia virus (BLV), proposed control and eradication programs by marker assisted breeding of genetically resistant cattle. In: RECHI, 
L. J. (Ed.) Animal genetics. Hauppauge, NY: Nova Science Publishers, 2009. p. 107-130.

FARIAS, M. V.; LENDEZ, P. A.; MARIN, M.; QUINTANA, S.; MARTÍNEZ-CUESTA, L.; CERIANI, M. C.; DOLCINI, G. L. Toll-like receptors, IFN-gamma and IL-12 expression in bovine leukemia virus-infected animals with low or high proviral load. Research in Veterinary Science, v. 107, p. 190-195, 2016. doi: 10.1016/j. rvsc.2016.06.016.

FERRER, J. F. Bovine lymphosarcoma. Advances in Veterinry Science and Comparative Medicine, v. 24, p. 1-68, 1980.

GARCÍA-BRIONES, M. M.; RUSSELL, G. C.; OLIVER, R. A.; TAMI, C.; TABOGA, O.; CARRILLO, E.; PALMA, E. L.; SOBRINO, F.; GLASS, E. J. Association of bovine DRB3 alleles with immune response to FMDV peptides and protection against viral challenge. Vaccine, v. 19, n. 9-10, p. 1167-1171, 2000. doi: 10.1016/S0264-410X(00)00313-3.

GILLET, N.; FLORINS, A.; BOXUS, M.; BURTEAU, C.; NIGRO, A.; VANDERMEERS, F.; BALON, H.; BOUZAR, A. B.; DEFOICHE, J.; BURNY, A.; REICHERT, M.; KETTMANN, R.; WILLEMS, L. Mechanisms of leukemogenesis induced by bovine leukemia virus: prospects for novel anti-retroviral therapies in human. Retrovirology, v. 4, n. 18, p. 1-32, 2007. doi: 10.1186/17424690-4-18.

GLASS, E. J.; BAXTER, R.; LEACH, R. J.; JANN, O. C. Genes controlling vaccine responses and disease resistance to respiratory viral pathogens in cattle. Veterinary Immunology and Immunopathology, v. 148, n. 1-2, p. 90-99, 2012a. doi: 10.1016/j.vetimm.2011.05.009.

GLASS, E. J.; CRUTCHLEY, S.; JENSEN, K. Living with the enemy or uninvited guests: functional genomics approaches to investigating host resistance or tolerance traits to a protozoan parasite, Theileria annulata, in cattle. Veterinary Immunology and Immunopathology, v. 148, p. 178-189, 2012b.

GUTIERREZ, S. E.; DOLCINI, G. L.; ARROYO, G. H.; RODRIGUEZ DUBRA, C.; FERRER, J. F.; ESTEBAN, E. N. Development and evaluation of a highly sensitive and specific blocking enzyme-linked immunosorbent assay and polymerase chain reaction assay for diagnosis of bovine leukemia virus infection in cattle. American Journal of Veterinary Research, v. 62, n. 1-2, p. 1571-1577, 2001. doi: 10.1016/j.vetimm.2012.03.006.

HOPKINS, S. G.; DIGIACOMO, R. F. Natural transmission of bovine leukemia virus in dairy and beef cattle. Veterinary Clinics of North America: Food Animal Practice, v. 13, n. 1, p. 107-128, 1997. doi: 10.1016/ S0749-0720(15)30367-4.

JULIARENA, M. A.; BARRIOS, C. N.; CERIANI, M. C.; ESTEBAN, E. N. Hot topic: Bovine leukemia virus (BLV)-infected cows with low proviral load are not a source of infection for BLV-free cattle. Journal of Dairy Science, v. 99, n. 6, p. 4586-4589, 2016. doi: 10.3168/ jds.2015-10480.

JULIARENA, M. A.; GUTIERREZ, S. E.; CERIANI, C. Determination of proviral load in bovine leukemia virusinfected cattle with and without lymphocytosis. American Journal of Veterinary Research, v. 68, n. 11, p. 1220-1225, 2007. doi: 10.2460/ajvr.68.11.1220.

JULIARENA, M. A.; POLI, M.; SALA, L.; CERIANI, C.; GUTIERREZ, S.; DOLCINI, G.; RODRÍGUEZ, E. M.; MARIÑO, B.; RODRÍGUEZ-DUBRA, C.; ESTEBAN, E. N. Association of BLV infection profiles with alleles of the BoLA-DRB3.2 gene. Animal Genetics, v. 39, n. 4, p. 432-438, 2008. doi: 10.1111/j.1365-2052.2008.01750.x.

KABEYA, H.; OHASHI, K.; OYUNBILEG, N.; NAGAOKA, Y.; AIDA, Y.; SUGIMOTO, C.; YOKOMIZO, Y.; ONUMA, M. Up-regulation of tumor necrosis factor alpha mRNA is associated with bovine-leukemia virus (BLV) elimination in the early phase of infection. Veterinary Immunology and Immunopathology, v. 68 , n. $2-4$, p. $255-265$, 1999. doi: 10.1016/S01652427(99)00029-X.

KARIMURIBO, E. D.; MORRISON, L. J.; BLACK, A.; TURNER, C. M.; KAMBARAGE, D. M.; BALLINGALL, K. T. Analysis of host genetic factors influencing African trypanosome species infection in a cohort of Tanzanian Bos indicus cattle. Veterinary Parasitology, v. 179, n. 1-3; p. 35-42, 2011. doi: 10.1016/j.vetpar.2011.02.001.

Braz. J. Vet. Res. Anim. Sci., São Paulo, v. 54, n. 3, p. 215-224, 2017 
KONNAI, S.; USUI, T.; IKEDA, M.; KOHARA, J.; HIRATA, T.; OKADA, K.; OHASHI, K.; ONUMA, M. Tumor necrosis factor-alpha genetic polymorphism may contribute to progression of bovine leukemia virusinfection. Microbes and Infection, v. 8, n. 8, p. 2163-2171, 2006. doi: 10.1016/j.micinf.2006.04.017.

LENDEZ, P. A.; PASSUCCI, J. A.; POLI, M. A.; GUTIERREZ, S. E.; DOLCINI, G. L.; CERIANI, M. C. Association of TNF-alpha gene promoter region polymorphisms in bovine leukemia virus (BLV)-infected cattle with different proviral loads. Archives of Virology, v. 160 , n. 8 , p. 2001-2007, 2015. doi: 10.1007/s00705-0152448-5.

LEWIN, H. A.; BERNOCO, D. Evidence for BoLA-linked resistance and susceptibility to subclinical progression of bovine leukaemia virus infection. Animal Genetics, v. 17, n. 3, p. 197-207, 1986.

LEWIN, H. A.; WU, M. C.; STEWART, J. A.; NOLAN, T. J. Association between BoLA and subclinical bovine leukemia virus infection in a herd of Holstein-Friesian cows. Immunogenetics, v. 27, n. 5, p. 338-344, 1988. doi: 10.1007/BF00395129.

MAILLARD, J. C.; CHANTAL, I.; BERTHIER, D.; THEVENON, S.; SIDIBE, I.; RAZAFINDRAIBE, H. Molecular immunogenetics in susceptibility to bovine dermatophilosis: a candidate gene approach and a concrete field application. Annals of the New York Academy of Science, v. 969, p. 92-96, 2002. doi: 10.1111/j.17496632.2002.tb04357.x.

MIRSKY, M. L.; OLMSTEAD, C.; DA, Y.; LEWIN, H. A. Reduced bovine leukaemia virus proviral load in genetically resistant cattle. Animal Genetics, v. 29, n. 4, p. 245-252, 1998. doi: 10.1046/j.1365-2052.1998.00320.x.

MIYASAKA, T.; TAKESHIMA, S. N.; JIMBA, M.; MATSUMOTO, Y.; KOBAYASHI, N.; MATSUHASHI, T.; SENTSUI, H.; AIDA, Y. Identification of bovine leukocyte antigen class II haplotypes associated with variations in bovine leukemia virus proviral load in Japanese Black cattle. Tissue Antigens, v. 81, n. 2. p. 72-82, 2013. doi: 10.1111/tan.12041.
NIKBAKHT BRUJENI, G.; GHORBANPOUR, R.; ESMAILNEJAD, A. Association of BoLA-DRB3.2 Alleles with BLV Infection Profiles (Persistent Lymphocytosis/ Lymphosarcoma) and Lymphocyte Subsets in Iranian Holstein Cattle. Biochemical Genetics, v. 54, n. 2, p. 194207, 2016. doi: 10.1007/s10528-016-9712-6.

PANEI, C. J.; SUZUKI, K.; ECHEVERRÍA, M. G.; SERENA, M. S.; METZ, G. E.; GONZÁLEZ, E. T. Association of BoLA-DRB3.2 Alleles with Resistance and Susceptibility to Persistent Lymphocytosis in BLV Infected Cattle in Argentina. International Journal of Dairy Science, v. 4, n. 3, p. 123-128, 2009. doi: 10.3923/ ijds.2009.123.128.

RUPP, R.; HERNANDEZ, A.; MALLARD, B. A. Association of bovine leukocyte antigen (BoLA) DRB3.2 with immune response, mastitis, and production and type traits in Canadian Holsteins. Journal of Dairy Science, v. 90 , n. 2, p. 1029-1038, 2007. doi: 10.3168/jds.S00220302(07)71589-8.

SCHWAB, A. E.; GEARY, T. G.; BAILLARGEON, P.; SCHWAB, A. J.; FECTEAU, G. Association of BoLA DRB3 and DQA1 alleles with susceptibility to Neospora caninum and reproductive outcome in Quebec Holstein cattle. Veterinary Parasitology, v. 165, n. 1-2, p. 136-140, 2009. doi: 10.1016/j.vetpar.2009.07.004.

STEAR, M. J.; DIMMOCK, C. K.; NEWMAN, M. J.; NICHOLAS, F. W. BoLA antigens are associated with increased frequency of persistent lymphocytosis in bovine leukaemia virus infected cattle and with increased incidence of antibodies to bovine leukaemia virus. Animal Genetics, v. 19, n. 2, p. 151-158, 1988. doi: 10.1111/j.13652052.1988.tb00800.x.

SULIMOVA, G. E.; UDINA, I. G.; SHAĬKHAEV, G. O.; ZAKHAROV, I. A. DNA polymorphism of the BoLADRB3 gene in cattle in connection with resistance and susceptibility to leukemia. Genetika, v. 31, n. 9, p. 12941299, 1995.

TAKESHIMA, S. N.; AIDA, Y. Structure, function and disease susceptibility of the bovine major histocompatibility complex. Animal Science Journal, v. 77, n. 2, p. 138-150, 2006. doi: 10.1111/j.1740-0929.2006.00332.x. 
TAKESHIMA, S. N.; GIOVAMBATTISTA, G.; OKIMOTO, N.; MATSUMOTO, Y.; ROGBERGMUÑOZ, A.; ACOSTA, T. J.; ONUMA, M.; AIDA, Y. Characterization of bovine MHC class II DRB3 diversity in South American Holstein cattle populations. Tissue Antigens, v. 86, n. 6, p. 419-430, 2015. doi: 10.1111/ $\tan .12692$.

UDINA, I. G.; KARAMYSHEVA, E. E.; TURKOVA, S. O.; ORLOVA, A. R.; SULIMOVA, G. E. Genetic mechanisms of resistance and susceptibility to leukemia in Ayrshire and black pied cattle breeds determined by allelic distribution of gene Bola-DRB3. Genetika, v. 39, n. 3, p. 383-396, 2003.

XU, A.; VAN EIJK, M. J.; PARK, C.; LEWIN, H. A. Polymorphism in BoLA-DRB3 exon 2 correlates with resistance to persistent lymphocytosis caused by bovine leukemia virus. Journal of Immunology, v. 151, n. 12, p. 6977-6985, 1993.
YOSHIDA, T.; FURUTA, H.; KONDO, Y.; MUKOYAMA, H. Association of BoLA-DRB3 alleles with mastitis resistance and susceptibility in Japanese Holstein cows. Animal Science Journal, v. 83, n. 5, p. 359-366, 2012. doi: 10.1111/j.1740-0929.2011.00972.x.

YOSHIDA, T.; MUKOYAMA, H.; FURUTA, H.; KONDO, Y.; TAKESHIMA, S. N.; AIDA, Y.; KOSUGIYAMA, M.; TOMOGANE, $\mathrm{H}$. Association of the amino acid motifs of BoLA-DRB3 alleles with mastitis pathogens in Japanese Holstein cows. Animal Science Journal, v. 80, n. 5, p. 510519, 2009. doi: 10.1111/j.1740-0929.2009.00664.x.

ZANOTTI, M.; POLI, G.; PONTI, W.; POLLI, M.; ROCCHI, M.; BOLZANI, E.; LONGERI, M.; RUSSO, S.; LEWIN, H. A.; VAN EIJK, M. J. Association of BoLA class II haplotypes with subclinical progression of bovine leukaemia virus infection in Holstein-Friesian cattle. Animal Genetics, v. 27, n. 5. p. 337-341, 1996. 